\title{
Announcements
}

\section{Editorial \\ The Need for a Global Paleoclimate Observing System}

A major obstacle standing in the way of producing reliable predictions of climate change and its impacts is a lack of data on timescales longer than the short instrumental record. Recently initiated climate observation programs will need to be continuously operated for at least 50 years before they begin to provide information that is relevant to this problem. Natural archives of past climate variability can provide relevant information now. Unfortunately, some of the most valuable paleoclimate archives are being rapidly destroyed, largely due to human influences. PAGES therefore calls on scientists, funding agencies and institutional partners to establish immediately a coordinated international Global Paleoclimate Observing System (GPOS) to complement and participate in the recently established Global Climate, Terrestrial and Ocean Observing Systems (GCOS, GTOS, GOOS) that focus only on contemporary observations (Alverson et. al (2001); Koenig (2001)).

A primary example of the loss of paleoarchives is the ongoing rapid retreat of alpine glaciers in both the tropics and temperate latitudes. Ice cores from such glaciers have been used to reconstruct temperature, precipitation and atmospheric dust levels and to provide records of changes in the strength of the Asian monsoon and ENSO. As shown in the figure on the cover of this issue the total area of the summit glacier on Kilimanjaro decreased by $82 \%$ between 1912 and 2000. Soon, the only information left from the Kilimanjaro ice will be what is left of the cores extracted last year by LonnieThompson and his group and stored in freezers at Ohio State University. The situation on Kilimanjaro is not an isolated one. Tropical warming is causing the rapid retreat of ice caps and glaciers at high elevations in the tropics and subtropics around the world. An extensive overview of the status of glaciers around the world is available on the world glacier monitoring service web site (http://www.geo.unizh.ch/wgms/).

PAGES exists to facilitate interdisciplinary collaboration, provide publicly available paleoenvironmental data archives, and coordinate the efforts of the maze of publicly supported databases. PAGES will continue to work with the research community, and representatives of major paleoenvironmental database efforts, to ensure long term, open archiving of paleoclimate data. The collection of data already at the PAGES supported World Data Center for Paleoclimatology (http://www.ngdc.noaa.gov/paleo/) is enormously valuable. Get your site on the map!

\section{Keith Alverson}

PAGES International Project Office, Bern, Switzerland alverson@pages.unibe.ch

\section{REFERENCES}

Koenig 2001, Science, 293, 31

Alverson et. al 2001, Science, 293, 47-48.

\section{Quaternary Environmental Change in the Indonesian Region}

Rien A.C. Dam ${ }^{1}$, Sander van der KaArs ${ }^{2}$ and A. Peter Kershaw ${ }^{3}$

1 rdam@nuffic.nl; 2 Sander.vanderkaars@arts.monash.edu.au; 3 Peter.kershaw@arts.monash.edu.au

Numbers on the map refer to the contents of the special issue of Palaeo3, Volume 171 : Introduction: Quartenary environmental change in the Indonesian region 1: A 40,000 year palynological record from north-east Thailand; implications for biogeography and palaeoenvironmental reconstruction 2: Environmental change in the Late Pleistocene and later Holocene at Wanda Site, Soroako, South Sulawesi, Indonesia 3: Palaeoenvironmental developments in the Lake Tondano area (N. Sulawesi, Indonesia) since 33,000 years B.P. 4: Palaeoecology, palynology and palaeolimnology of a tropical lowland swamp: Rawa Danau, West-Java, Indonesia 5: A Late Pleistocene and Holocene pollen and charcoal record from peat swamp forest, Lake Sentarum Wildlife Reserve, West Kalimantan, Indonesia 6: Late Quaternary tropical lowland environments on Halmahera, Indonesia 7: Biomass Burning in Indonesia and Papua New Guinea: natural and human induced fire events in the fossil record 8: Late Quaternary peat formation and vegetation dynamics in a lowland tropical swamp; Nee Soon, Singapore 9: Evidence for continued disturbance of upland rain forest in Sumatra for the last 7,000 years of an 11,000 year record 10: The geoarchaeology of the prehistoric ditched sites of the upper Mae Nam Mun valley, N.E. Thailand, III: Late Holocene vegetation history 11: Pollen-stratigraphic evidence of human activity at Dieng, Central Java 12: Pollen distribution in marine sediments from the southeastern Indonesian waters 13: The evolutionary history of humans in Australasia from an environmental perspective 14: The Late Quaternary palaeogeography of mammal evolution in the Indonesian Archipelago 15: Late Quaternary Terrestrial Vertebrates From Palawan Island, Philippines.

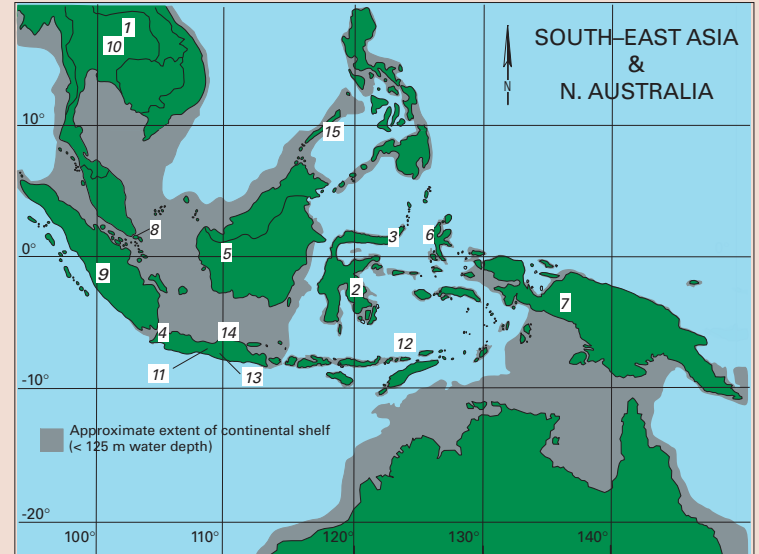

To highlight results of recent studies in the vital, but poorly understood equatorial region, a special volume (No. 171, July 2001) of the journal Palaeogeography, Palaeoclimatology, Palaeoecology is dedicated to Quaternary environmental change in the Indonesian region. A total of 15 research papers contain a wealth of palaeoenvironmental and palaeoecological information relevant for the attempts to integrate palaeoclimate data within the PEP II transect. 